\title{
10 Why radical transformation is necessary for gender equality and a zero carbon European construction sector
}

\author{
Linda Clarke and Melahat Sahin-Dikmen
}

\section{Introduction}

Under capitalism, the domination and exploitation of labour are inseparable from those of nature (Parsons, 1977), and there is perhaps no sector where this is more apparent than in construction, an industry with often poor working and employment conditions and one responsible for a high proportion of carbon emissions, including through extensive use of cement (Bataille, 2019). Construction is also a male-dominated industry where it has proved very difficult to improve women's historically low levels of participation, averaging around 10\% in Europe although varying between countries and occupations. This chapter identifies both the constraints involved in meeting zero energy targets and those that have served to exclude women. It seeks to show why and how incorporating women's interests and experiences will help to ensure equitable outcomes and contribute significantly to the successful transformation of the construction sector into an eco-industry.

The climate emergency has highlighted many of the weaknesses of the industry, in particular the priorities of healthy and safe employment and working conditions, and together with the 2020 arrival of a coronavirus crisis, these have prompted an urgent, long-overdue drive for change. Construction is a sector set to gain more employment than any other from the transition to a green economy through policies and programmes for nearly zero energy building (NZEB), renewable energy installations and retrofit across Europe (ILO, 2018). This opens up opportunities for women and, at the same time, for overcoming the structural, organisational and cultural obstacles to their inclusion. However, the pursuit of the European Union's (EU), green transition policy for the built environment is focused on ecologically modernising an industry without addressing the social relations and structures that characterise the sector and hinder its ability to reduce carbon emissions (Foster, 2002; Hampton, 2015; Lundström, 2018). At the same time, the mainstream approach to achieving gender equality in the sector is narrowly focused on recruiting more women and similarly fails to address the employment and working conditions that give rise to their exclusion in the first place. 
The chapter begins by outlining women's participation in construction and approaches to addressing gender inequalities. Also drawing on the experiences of women themselves, the reasons for the failure of policies and practices to improve the participation of women are pinpointed, both in the vocational education and training (VET) system and the labour market. There follows a review of the EU's policy to reduce carbon emissions associated with the built environment, revealing its premises and consequent gender blindness and lack of attention to the social aspects of building production. The crucial importance of addressing these for effectively implementing the European Performance of Buildings Directive (EPBD) is then addressed, both in relation to VET and the labour process requirements for low energy construction (LEC). Finally, examples of good practice are presented, highlighting the role of different stakeholders and pointing to what is required for gender-sensitive, equitable, and socially sustainable employment in a green construction sector. The chapter concludes by suggesting that a comprehensive retrofit and new-build NZEB programme can be the means of transforming the industry to become socially useful and carbon-neutral, driven by social concerns and involving women and their representative organisations in shaping institutional strategies at all levels.

\section{Why are so few women found in the construction sector?}

Women's participation in the construction sector is low across Europe, averaging 10\% in 2018 and ranging from 13\% in Germany and Austria, 11\% in the UK and $10 \%$ in France down to only 7\% in Denmark and Greece and 6\% in Italy, Poland, Romania and Ireland (ECSO, 2020). These figures include, however, both those in the professions and in the operative workforce and participation is higher for the professions, as apparent from Table 10.1, particularly in Eastern European countries. Women represented $43 \%$ of graduates from engineering, manufacturing and construction in Poland and $37 \%$ in Romania, in contrast to central

Table 10.1 Graduates in engineering, manufacturing and construction 2018

\begin{tabular}{lccrlc}
\hline Country & $\begin{array}{l}\text { Number } \\
\text { of women } \\
\text { graduating }\end{array}$ & $\begin{array}{l}\text { Number } \\
\text { of men } \\
\text { graduating }\end{array}$ & Total & $\begin{array}{l}\text { \% of women } \\
\text { graduating }\end{array}$ & $\begin{array}{l}\text { \% women } \\
\text { employed in narrow } \\
\text { construction sector }\end{array}$ \\
\hline Denmark & 2,607 & 7,188 & 9,795 & 27 & 7.2 \\
France & 2,512 & 84,421 & 110,933 & 24 & 9.6 \\
Germany & 26,379 & 94,449 & 120,828 & 22 & 12.8 \\
Italy & 19,415 & 42,014 & 61,429 & 32 & 5.9 \\
Norway & 1,846 & 5,458 & 7,304 & 25 & 6.3 \\
Poland & 29,049 & 39,321 & 68,371 & 43 & 6.2 \\
Romania & 7,997 & 13,622 & 21,619 & 37 & 10.7 \\
Switzerland & 2,276 & 11,801 & 14,077 & 16 & \\
UK & 18,136 & 55,953 & 74,090 & 25 & 16 \\
\hline
\end{tabular}

Sources: Eurostat (2018), ECSO (2020) Improving the human capital basis, European Construction Sector Observatory: 28 
European countries, Scandinavian countries and the UK at between 22\% and $27 \%$, with only Italy faring better at $32 \%$ and Switzerland worse at $16 \%$. Across Europe, too, Eurostat figures on female engineering workers employed as a share of the total engineering workforce show relatively high proportions, including in Bulgaria (30\%); Slovenia, Poland and Italy (20\%); Belgium and Hungary (19\%), Spain (17\%); and Germany, Ireland and Finland (15\%) (Clarke et al., 2015). And in the UK, a significant proportion of women is found in technical positions in construction (24\%), such as quality assurance technicians (39\%) and quality control and planning engineers (19.1\%) (Clarke et al., 2019).

Of those employed in the energy sector, $22 \%$ are women and these are generally in lower paid and not managerial jobs, though there is an increasing requirement for those with scientific knowledge and specialist expertise (EIGE, 2016a). In the renewables sector, too, though women are estimated to represent $35 \%$ of those employed across Europe, in Germany, Italy and Spain they hold less than $30 \%$ of jobs, most of which are similarly low paid, non-technical, or administrative rather than technical, managerial, or involving policy-making (IRENA, 2019). Occupations belonging to the operative workforce in the renewables sector, many of which are construction, tend to be heavily male-dominated, including metal workers, insulation specialists, plumbers, pipefitters, electricians and heating and cooling experts (Clancy and Feenstra, 2019).

Though there has been more progress in the professions, what is surprising concerning the participation of women in the construction operative workforce is the shockingly slow or non-existent pace of change. In 2016, only 3\% of those employed across the EU were women (Eurostat, 2016), a figure that has remained relatively stable, apart from during the world wars, for well over a century. The reasons for this poor representation have been well-researched and are generally attributed to: structural, organisational and cultural obstacles, including the lack of formalised recruitment practices and procedures and inappropriate selection criteria; employment conditions, in particular the fragmented nature of employment and lack of support and work-life balance possibilities; inflexible and hazardous working conditions, such as long working hours and inappropriate equipment; and less tangible obstacles, such as the lack of knowledge and poor image of the sector, traditional stereotypes, sexist attitudes and a male-dominated culture, network, and environment (Fielden et al., 2000; Clarke et al., 2004, 2015; Worrall et al., 2010; Sang and Powell, 2013; Baruah, 2018; Clancy and Feenstra, 2019). In terms of ability, however, equal competence has been shown (e.g. Arditi et al., 2013).

The most pervasive reason for exclusion is the working conditions, above all the long working hours, both on sites and in the professions (Watts, 2009; Styhre, 2011; Caren and Astor, 2013). Indeed, in a 'virtual' meeting with women working in construction from the USA and different European countries held during the coronavirus pandemic, working conditions, above all related to health and safety, were the dominant source of complaint, including shift hours, lack of washing, toilet and changing facilities and of personal protective equipment suitable for women, social distancing, site cleansing and risk assessments. The 
increasing fragmentation of the construction process through subcontracting and self-employment have also aggravated the exclusionary nature of the industry, but its stubborn persistence, despite all the efforts to increase the number of women, suggests deeply embedded structural obstacles and a gendered division of labour that is unlikely to change without a social transformation.

The solutions to greater female participation also vary, with much emphasis placed on corporate social responsibility and human resource management (HRM), including mentoring and networking (Clancy and Feenstra, 2019; ECSO, 2020). In addition to these, Worrall et al. (2020, p. 280), in a perfect illustration of 'neo-liberal' onus placed on women themselves to accommodate to male domination (Fraser, 2013; Rottenberg, 2018; Ferguson, 2020), advocate support systems and continuing professional development:

providing women with the necessary 'soft skills' in communication, people management and confidence building that equips them to negotiate difficult working environments and male-dominated organisational cultures.

The remit of the unfortunately named EC-funded initiative, High heels: building opportunities for women in the construction sector (ECSO, 2020, p. 81), covering Bulgaria, Greece, Romania and Cyprus, follows this advice, seeking to train women to 'strengthen their soft skills in order to improve the performance of the construction sector'. Such strategies, in their acceptance of gender discrimination, devalue women and fail to challenge - and even succeed in maintaining the gendered nature of construction and engineering (Powell et al., 2009; Watts, 2009). Other HRM-inspired solutions involve awareness-raising, including through training trainers in 'gender sensitivity' (ECSO, 2020, p. 81). As Clarke et al. (2018) argue, such employer-led, top-down, 'business case' approaches to achieving diversity in STEM occupations lack effectiveness through the absence of involvement from other stakeholders, especially employees and target groups, allowing only a fraction of diversity-related issues to be 'visible' in the organisation, while others remain 'suppressed'.

Stronger and more systematic solutions have been more successful, if only temporarily. These include targeted measures and monitoring and enforcement to improve access to and retention in green jobs, though too often employers meet procurement diversity requirements only to let women go as soon as the contract is secured (Baruah, 2018). Incremental measures are also proposed that seek to directly alleviate and improve working conditions for those women working in construction, including working in pairs and improved lighting. Overall, however, despite all the efforts over many decades, little has changed. As Baruah $(2018$, p. 3) complains, most policies are 'reactive responses that do not engage adequately with broader societal structures and institutions that produce and maintain inequality'. Indeed, over two decades ago, Dainty et al. (1999) questioned efforts to increase the number of women in construction given that workplace practices were geared to men's needs, including long working hours, geographical instability and the subordination of personal lives. They showed 
how men progress in the industry vertically through networking and informal mechanisms, whilst women focus on coping with a male environment, and concluded that the only way for women to further their careers was to leave. In raising doubts as to whether women should be attracted to an industry 'ill-equipped for employing them', therefore, Dainty et al. (1999, pp. 356-357) challenged existing measures and insisted that:

It is only through a genuine commitment to the development of a more equitable industry from the highest level, that women are likely to be able to develop their careers in parity with men.

But how does gender inequality in construction fare in policies formulated at the highest level in the EU today? Does gender feature in visions of a future sustainable industry? More specifically for the purposes of this chapter, to what extent does the EU green transition policy for the built environment address gender inequalities?

\section{The EU energy-efficiency policies and gender}

Being responsible for $36 \%$ of $\mathrm{CO} 2$ emissions and $40 \%$ of energy consumption, the built environment is targeted for a major transformation as part of EU climate change action plans, (EC, 2019a). The energy strategy up to 2020 is set out in EU2020 development plans and designed in accordance with Paris Agreement targets, aiming to reduce energy use, improve energy efficiency and the use of renewable energy, each by $20 \%$, compared to 1990 levels (EC, 2010). For 20212030, adaptation measures for the built environment are set out in Clean Energy for All Europeans (EC, 2019a). In the medium term, these include a package of initiatives with the aim of improving energy efficiency by $32.5 \%$, increasing the share of renewable energy by $32 \%$ and reducing $\mathrm{CO} 2$ emissions by $40 \%$ by 2030 . It is planned to be progressed in tandem with the European Green Deal (EC, 2019a), the EU's strategic programme for implementing the UN's 2030 Agenda. Improving the energy efficiency of buildings is fundamental to achieving these targets and this is driven by the $\operatorname{EPBD}(2010,2018)$, which requires that all new buildings are NZEB by the end of 2020. The EPBD provides the overarching legislative framework, setting out the technical definition of NZEB and guidance for its implementation, whilst member states are responsible for its transposition into national law. Thus, although the exact technical specifications vary, NZEB means higher energy performance standards for all $\mathrm{EU}$ countries.

On closer review, it is apparent that these key policies concerning the green transition in the built environment are underpinned by the logic of consensus of the technologically driven ecological modernisation approach, which is oriented to innovation and argues for the economic benefits of environmentalism (Mol et al., 2009; Machin, 2019). This approach is evident from the stated objectives of the energy policy over the last two decades of achieving an energy-efficient and carbon-neutral European economy (including in the built environment and 
transport) and a fully integrated pan-European energy market by 2050 by ensuring energy security through cooperation between $\mathrm{EU}$ countries, increasing renewable energy, supporting research and innovation into clean energy technologies, empowering consumers and strengthening the EU's external energy relations (EC, 2015, 2019a). The Green Deal (EC, 2019b) similarly sets out decarbonisation strategies and emphasises the role of technology in increasing the share of renewable energy and the potential of renovating Europe's building stock, giving further considerations to the legislation, public investment and private financing and education and training. Both the energy policy and the Green Deal highlight job creation as an anticipated outcome, particularly through energy efficiency improvement measures in buildings and growth in the renewable energy sector, which alone are expected to employ two million people by the end of 2020, mostly in the construction industry.

EPBD implementation measures and plans required of the member states, such as setting minimum energy performance standards, adaptation of technical building systems, energy performance certificates and inspection regimes, further illustrate the technocratic framing of the transition to sustainable construction. For example, between 2007 and 2020 implementation was facilitated by National Energy Efficiency Action Plans (NEEAPs), setting out the adapted definition of NZEB, the energy efficiency measures to be pursued, energy performance certification, inspection schemes and financial incentives, as well as developing renovation strategies and other complementary measures to achieve the now superseded EU 2020 targets (EPBD, 2010, 2018; EC, 2016a). The ten-year National Energy and Climate Plans (NECPs) for the next decade are required to outline, in a similar way, what legislative, financial and regulatory measures will be put in place to meet the 2030 targets and indicate a long-term strategy towards 2050 (EC, 2019a).

In none of these policy documents on energy, the EPBD, or the NECPs is there any reference to women or gender. The energy efficiency strategy of the last two decades has made no provision to address women's participation in this transition, neither catering to their education and training needs nor taking measures to ensure that they gain advantage from emerging employment opportunities. The only nod to the social aspects of the transition is the Build $U_{p}$ Skills initiative (BUS), launched to increase the number of building workers trained in the competencies needed for low energy construction (LEC) and subsequent Horizon 2020 funded training programmes (EC, 2014, 2016b, 2018). However, these made no provisions to address gender inequalities in the sector, despite EU attempts to 'add' gender (Allwood, 2014) to existing policies, focused on increasing the number of women particularly in STEM (science, technology, engineering and mathematics) education and the renewable energy sector (EIGE, 2016a, b).

This does not mean that the EU does not legislate for gender equality. On the contrary, gender equality remains an explicit objective and gender mainstreaming has been a commitment since 1996, following the formation of the Beijing Platform of Action (EIGE, 2012). This commitment is articulated, for example, 
in Article 23 of the Charter of Fundamental Rights (European Parliament, 2012c) and in calls by the European Parliament for gender equality in the green economy and for the inclusion of women at all levels of decision-making (European Parliament, 2012a, b). Further, gender equality is comprehensively covered by the European Pillar of Social Rights (European Parliament, 2017) in terms of employment (access, progression, pay), equal opportunities (non-discrimination to cover education and all other social services) and work-life balance. The recently updated Gender Equality Strategy (EC, 2020) renews the commitment to gender mainstreaming to ensure women's participation in decision-making, including on climate change, and acknowledges intersectionality as critical to understanding the complexity of disadvantage and inequality, away from essentialising male-female binaries.

There is, therefore, a seeming contradiction between formal and loud commitment to gender equality on the one hand and the 'silence' (Bakker, 2015) of green construction policies on gender inequalities on the other. For explanation, feminist institutional analyses turns the lens to institutions and the structures, power relations and formal and informal processes that work to prevent a gender perspective from being integrated into specific public policies (Weiner and MacRae, 2014). Whilst women's presence is no guarantee that a gender perspective will have a fair hearing, what difference are women participating in climate policy actually making? Few ministers of energy, within which the green construction strategy is subsumed, are women, and the construction sector too is particularly male-dominated (Clancy and Feenstra, 2019). Even when women are present, power imbalances within institutions, established and taken for granted prioritisation of sector-specific issues, and the interpretation of gender mainstreaming by the different actors involved, all contribute to the marginalisation of gender issues in the policy-making process (Weiner and MacRae, 2014). Organisations are 'sticky' and path dependent and there is a limit to how far institutional agendas can be challenged. The result is that gender equality, rather than being a fundamentally cross-cutting issue, continues to be tackled as an add-on to discreet areas of policy and gender mainstreaming becomes a box-ticking exercise that does not lead to change on the ground (Arora-Jonsson, 2017; MacGregor, 2017).

This discretion is exemplified in documents produced by the European Institute for Gender Equality (EIGE), in particular on Gender and Energy (EIGE, 2016a) and Gender in environment and climate change (EIGE, 2016b). These recognise the serious underrepresentation of women in higher technical and scientific education and employed in the energy sector, including in renewable energy and climate change decision institutions. They call for: a 'more balanced representation of women' at all levels in the field of climate change mitigation; support for women in science and technology; the elimination of gender stereotypes and promotion of gender equality in education, training, and working life; and the integration of the principle of gender mainstreaming into relevant legislation, policy measures and instruments related to climate change mitigation (EIGE, 2016b). However, there is no consideration given to social and economic relations, such as the gendered division of labour, which give rise to the low participation of 
women in the first place or to structural problems in the sectors themselves that perpetuate gender inequality and need to be transformed. Policy is, instead, directed to inserting women and increasing participation in sectors structurally aligned to reproduce gender segregation and falls far short of the social transformation needed.

Whilst the democratisation of and equal representation in environmental governance are critical, therefore, a deeper challenge to the dominant policy paradigm is necessary to put gender equality at the centre of visions for a sustainable Europe. The current EU approach to gender mainstreaming is, on one level, a manifestation of the underlying neo-liberal political and economic rationale that externalises social reproduction and separates gender inequality, which is dealt with as a question of equal rights and opportunities and discrimination, from issues of the 'real economy', including industrial, economic, or climate policy-making (Mellor, 2017; McGregor, 2010). Relegating gender inequality and the gendered division of labour in society to a separate platform is, thus, predicated on giving individual women the equal opportunity and 'support' they need to compete for jobs, while the patriarchal structures and practices and existing exploitative and unsustainable employment practices that shape their participation and progress in paid employment, including in construction, are ignored (Fraser, 2013; Rottenberg, 2018; Ferguson, 2020). This lack of attention to the gender implications and context of construction parallels and is not separate from the neglect of entrenched problems of construction labour markets and VET, which also hinders the pursuance of green transition policies.

\section{Putting the 'social' back into green construction policies: Labour and VET}

EU green construction policy is thus gender blind and generally lacking a social perspective; climate change, energy transition, and energy efficiency are formulated as neutral, scientific systems and processes with little social context or implications (Machin, 2019). The EU's ecological modernisation approach and climate change policies, driven by technical targets and market priorities, are all the more disquieting given that the transition to NZEB has significant consequences for the employment, education, and training of the construction workforce. LEC is fundamentally different from the traditional construction process as it introduces the concept of energy performance into a production system driven by building to time and budget. Buildings must meet specific energy performance targets through such measures as airtight building envelopes, thermal-bridge free construction, and on-site renewable energy sources. LEC, thus, needs a greater degree of precision and careful co-ordination so that building components are put together to constitute a system and function to restrict energy use to pre-determined limits. For the construction labour process, these requirements imply overcoming interfaces between different occupations, integrated team working, and improved communication given the complex work processes involved (Clarke et al., 2017a). Meeting these depends on an adequately trained workforce and 
expertise distinct from that developed in traditional construction VET, calling for broader qualification profiles, deeper theoretical knowledge, and higher technical competences to acquire thermal literacy, interdisciplinary understanding, and a broad range of transversal abilities such as project management and problemsolving. Incorrect and poor-quality installation results in a performance gap, the difference between the energy standards intended and those actually achieved, jeopardising the EPBD stipulated emission savings (Zero Carbon Hub, 2013; Johnston, 2016). Evidence suggests that failure to build to standards required indicates structural problems in terms of work organisation, employment, and the quality of VET (EC, 2014; Gleeson, 2016; Clarke et al, 2017a, 2019).

The BUS EU initiative (2010-2017), launched to develop NZEB competencies in the workforce, illustrates the complexity and the sheer scale of the task facing the industry (EC, 2014, 2016b, 2018). The BUS national status quo analyses, completed by member states highlight weaknesses in national VET systems and reveal that the number of construction workers in need of training runs into millions across the EU, with many having low general education levels and lacking formal training or qualifications. The overview report shows that most EU countries have a long way to go in upgrading occupational competences and learning resources, developing new courses and qualifications, and training the trainers, entailing a major programme of work. These challenges are compounded by under-resourced VET systems in many countries, with several also undergoing major reforms. Moreover, the scale of what is needed varies substantially between countries, and evaluation of VET for LEC reveals distinctive approaches, not all adequate for providing the expertise needed (Clarke et al., 2019).

Other imperatives also drive the requirement for more and improved VET, including an ageing workforce, the 'skills drain', increasing digitalisation and automation, changes in work organisation and the division of work, and the development of a circular economy (EFBWW and FIEC, 2020). In criticising the EU skills agenda for its 'homogeneous vision' and neglect of 'responsible partnership', the European construction social partners - the European Federation of Building and Woodworkers (EFBWW) and the European Construction Industry Federation (FIEC) - stress that the skills and VET agenda are interconnected with collective bargaining discussions on wages and working conditions. Indeed, the structure of the industry and its labour market characteristics - dominated by micro firms and casual and self-employment, facing a severe recruitment crisis, reliant on migrant labour, with many employers neither valuing nor seeing the need for qualifications - present a momentous challenge to VET and to retraining the construction workforce (Clarke et al., 2019). The challenge, therefore, is not simply a technical one of adapting to the demands of construction at a time of climate change, but of transforming the structure and organisation of the industry and the agency required of workers and reforming VET systems to take account of increased requirements for worker autonomy, integrated teamwork, project management awareness, and applied knowledge, as well as specific skill gaps.

Some of these problems are recognised, as recently highlighted in a report of the European Construction Sector Observatory (ECSO, 2020), Improving the 
human capital basis, which estimates that between three and four million workers need to develop energy efficiency-related skills in the industry. It identifies structural obstacles to this, including the fragmentation of the market and of construction value chains, cyclical factors, and the fact that 'many companies adopt a temporary employment model ... limiting incentives for long-term investment in the workforce' (ECSO, 2020, p. 53). Moreover, 75\% of companies struggle to follow occupational safety and health $(\mathrm{OSH})$ requirements and $40 \%$ do not work safely, so that OSH-related training must increase by $60 \%$ (ECSO, 2020). This is detrimental to the 'attractiveness' of the industry, whose poor image is associated with low job security, tough working conditions, and health and safety concerns. However, these obstacles and detrimental factors are not then the direct target of policy, and increasing women's participation in construction is even seen as one solution to improving the attractiveness of the sector (ECSO, 2020, p. 9). Just as policies to achieve a zero carbon built environment fail to address employment and working conditions, similarly, so too do those seeking to increase female participation and improve the 'image' of the industry, even though these conditions are underlying obstacles to achieving both gender equity and NZEB.

The very use of the term 'human capital' in the title of the ECSO (2020) report helps to explain why the social structures forming and constraining the quality and quantity of labour and the complexities of 'skill formation' at different levels are neglected. Human capital theory (Becker, 1993) has long been challenged for regarding the 'skills' or 'human capital' of the workforce as the property of individual workers and associated only with the work processes of particular firms (Maurice et al., 1986). This narrow conception of 'skills' inevitably ignores the socialisation of labour, including women, into production through structures of employment, wage relations, and training (Campinos Dubernet and Grando, 1991). Just as the ecological modernisation approach to a green transition of the European Commission (EC) is without concern for the quality of labour and employment involved or worker agency, so too is the human capital approach taken by ECSO, under the EC's Competitiveness of Enterprises and Small and Medium-sized Enterprises (COSME) programme on market conditions and policy developments in the European construction sector.

\section{Learning from examples of good practice}

Embedding gender equality in policy and enabling women to shape and participate in the emerging green transition in construction require a paradigm shift, implying a re-definition of terms. It has also been suggested that greater female participation could make for more sustainable practices, enhancing women's opportunities, and accelerating social and technical change (Pearl-Martinez and Stephens, 2016). Examples of the extensive involvement of women in the green transition are, however, rare and more common in the professions than for the operative construction workforce. There are, though, local and organisational cases where women have been employed on a sustained basis in construction 


\section{Linda Clarke and Melahat Sahin-Dikmen}

which, on examination, serve to identify some of the ingredients necessary for their successful participation. Where these ingredients are also conducive to effective LEC, and above all where organisations are also actively engaged in NZEB, a model is given for developing an eco-friendly and inclusive sector, in particular in terms of the coalition of actors involved.

One of the first ingredients needed for women's successful involvement in LEC is their ability to acquire the necessary qualifications. Given the requirement for high-level qualifications with LEC, good communication, and coordination skills, and the ability to manage the project, the way is potentially opened up for greater involvement of women, especially considering their generally higher educational achievements and greater presence on environmentally oriented courses and in technical, professional, administrative, and clerical functions (Clarke et al., 2017b). However, as indicated, any involvement is predicated on good and inclusive employment and working conditions. In this regard, large infrastructure projects in which women have been significantly involved, especially in the more professional areas, are useful for drawing out the measures that can facilitate their employment. These have included UK projects such as Heathrow Terminal 5, the 2012 Olympics, Crossrail, Thames Tideway Tunnel, and Hinkley Point Nuclear Power Station (Clarke et al., 2015; Baruah, 2018). The longevity, size, complexity, and nature of such major infrastructure projects mean that they are often highly regulated and subject to scrutiny, opening up the possibility for a more inclusive employment policy, setting ambitious targets, and new ways of working. For instance, the all-embracing Common Framework Agreement between EDF (Électricité de France) and unions at Hinkley Point places great emphasis on establishing integrated teams and new working practices and is structured to optimise opportunities to bring new people into the workforce (EDF, 2013). For the Olympics, contract compliance, continuous monitoring, and the guarantee of direct employment were critical to meeting equality targets (Wright, 2014). All in all, from examining these different mega projects, particular factors critical to the achievement of greater inclusivity are indicated the roles of public procurement; the significance of regulated agreements secured with key stakeholders, including local authorities and unions; the involvement of the workforce and women's groups; systematic, targeted, and controlled recruitment, proactively applying equal opportunities policies; guarantees of direct employment; close monitoring; well-conceived training programmes, facilitating broader occupational profiles, formal links with colleges and universities, work placements and work experience; and good working conditions, including structured working hours, childcare provision, flexible working arrangements, and mentoring (Clarke et al., 2015).

Whilst these examples point to some of the measures required for the successful involvement of women, they are at the same time short-lived and without significant environmental credentials, especially concerning the use of concrete and the building of nuclear power stations and airports. More sustained participation of women in construction in the UK is found in the building departments of local authorities, known as Direct Labour Organisations (DLOs), which have always 
prided themselves on good employment and working conditions. These have made concerted attempts to include women since the 1970s, particularly following the introduction of the Sex Discrimination Act (1975), making it illegal to discriminate on the grounds of sex in employment or education, and grassroots campaigning by women to set up women-only training workshops. Women, consequently, accessed training in construction occupations, which was consolidated by joining DLOs. By the mid-1980s, Hackney DLO in London, for example, was running one of the largest training schemes for building workers in Britain, in which over $50 \%$ of the adult trainees were women, many going on to permanent jobs in construction (Clarke et al., 2015). Local authorities committed to changing their male-dominated construction workforce created a framework of support for women through the provision of designated women's officers; regular meetings; placing more than one woman on any site; flexible hours of work; and a clear and transparent set of equal opportunities guidelines backed up by internal procedures to address grievances. The success of these measures is evident in the presence of 266 women in construction operative occupations in seven Inner London DLOs in 1989. This legacy of the 1980s survives, despite political challenges, and DLOs have continued to address the low numbers of young women seeking construction training. For example, of the 283 apprentices at Leicester DLO between 1985 and 2002, 84 (30\%) were women and, by 2012, 123 of its 431 strong workforce were women, as were 18 of the 75 apprentices employed in all occupations - as carpenters, electricians, plasterers, painters and decorators, bricklayers, heating and ventilating engineers, gasfitters, and metal workers (Clarke et al., 2015). This, therefore, provides us with further aspects necessary for the sustained employment of women: the involvement and commitment of public authorities, stable and direct employment, and a framework of support.

The different ingredients implied for the successful inclusion of women in construction can, therefore, be summarised as:

- Public sector involvement, especially, as in the aforementioned cases, the municipal authorities

- Good organisational employment and working conditions, targeted recruitment and retention, family-friendly policies

- Stakeholder involvement, as recommended in the Beijing Platform for Action, including women's organisations, professional bodies and unions

- Comprehensive training linked to employment

Whilst less impressive in terms of the participation of women, one organisation discovered in Scotland that fulfils most of these different criteria and has, at the same time, a clear commitment to NZEB is City Building Glasgow, which represents a sustained alternative employment model to the private sector. City Building Glasgow is a not-for-profit organisation, jointly owned by Glasgow City Council and the Wheatley Group Housing Association, and formed in 2006 from the original DLO of Glasgow City Council. Most of the 2,200 permanent construction employees of City Building Glasgow are unionised and the Joint Trade 
Union Council is actively engaged in the organisation and underpins its strong social ethos (Clarke et al., 2018a). The organisation is unique in directly employing, under decent standards, a large construction workforce, regulating and monitoring subcontracting through a framework agreement, and running an in-house training centre providing a comprehensive and acclaimed four-year programme for a diverse intake, including women, with most trainees staying on as employees. The organisation's LEC schemes built to varying energy efficiency standards include social housing, care homes, schools, hostels, and retrofitting social housing estates, including through the installation of district heating using air source heat pumps, as part of efforts to tackle fuel poverty. Environmental measures are, thus, intertwined with employment and training practices that prioritise workers in a model shaped by the enhancement of labour capacity and opportunities for direct engagement in the green transition and underpinned by the traditions of municipal socialism.

These case studies suggest that the transformation of construction into an inclusive, eco-industry needs the input of a range of other stakeholders such as public authorities, VET institutions, unions, women in construction and their representative organisations, environmental organisations, and employers and their associations. Thus, even though gender is given scant attention and women rarely sit around the table in European and national energy policy-making, stakeholder involvement and institutional interventions at more local, sectoral, and organisational levels can be exemplary and indicate potential and effective drivers of change.

\section{Conclusion}

The lack of gender diversity in construction is a critical issue, one that relates to barriers in terms of the nature of VET and employment, human resource policies and practices for the industry, and the lack of employee engagement. Many of these are also barriers to achieving effective NZEB, including the need for a comprehensive and high-standard VET system and a stable, safe, and healthy system of employment. The suggestion is that meeting the challenge of a green transition in construction opens up the possibility to include women. Raising standards in construction VET and in employment and working conditions will also help address the current Europe-wide recruitment crisis in construction. Technologically up-to-date, well-resourced and high-level VET leading to qualifications valued in the sector could make a career in construction an attractive option for women. And interesting, eco-friendly, socially useful, not-for-profit and challenging construction work, including large-scale retrofit programmes, can turn that option into a reality over which women can have a decisive say and impact. What is needed to strike a blow at carbon emissions in construction is a major retrofit initiative in which women and men, trained and employed on an equal basis, play a decisive role - one that serves as a demonstration of how the industry can be transformed to become inclusive and socially useful through producing a carbon neutral building stock. 
This chapter has sought to show how the EU's ecological modernisation approach and gender-blind policies in relation to energy mean that implementation of the EPBD is regarded as a technological fix. Yet, without addressing the social and structural problems besetting the construction industry, it will not only be impossible to achieve gender equality but also difficult to realise NZEB. Transforming the employment and working conditions that serve to exclude women and impede LEC is necessary both in order to meet energyefficient and low carbon emission targets and to become an inclusive eco sector. It is also essential to develop VET systems capable of qualifying the many thousands of construction workers required for NZEB and retrofit programmes across Europe. While some countries, including Germany and Belgium, are well on the way to upgrading their VET systems to incorporate LEC elements, their construction industries continue to exclude women. The examples given show where women have been successfully included and where NZEB has been achieved, and suggest the combination of factors and the coalition of stakeholders that will be needed to transform construction into an inclusive, socially useful eco-sector. These factors include direct employment, good working conditions, comprehensive and targeted VET for LEC programmes, NZEB and measures to support the inclusion of women, whilst the actors include local authorities, not-for-profit building organisations, unions, colleges and training centres and, above all, women. In this way, the chapter reveals how a gendered analysis helps to identify the structural problems in the sector that need to be overcome if a green transition and gender equality in construction are to be accomplished.

\section{References}

Allwood, G. (2014) 'Gender mainstreaming in EU climate change policy', in Weiner, E. and MacRae, R. (eds) The Persistent Invisibility of Gender in EU Policy. European Integration online Papers (EIoP), Special Issue18 (1), Article 6, http://eiop.or.at/eiop/ texte/2014-006a.htm, pp 1-26.

Arditi, D., Gluch, P. and Holmdahl, M. (2013) 'Managerial competencies of female and male managers in the Swedish construction industry', Construction Management and Economics, 31(9), pp. 979-990.

Arora-Jonsson, S. (2017) 'Gender and environmental policy', in MacGregor, S. (ed) Routledge Handbook of Gender and Environment. Abingdon and New York: Earthscan, pp. 289-303.

Bakker, I. (ed) (1995) Strategic Silence. London: Zed Books.

Baruah, B. (2018) Identifying Promising Policies and Practices for Promoting Gender Equity in Global Green Employment. Clean Economy Working Paper Series. Canada: Western University.

Bataille, C. (2019) Low and Zero Emissions in the Steel and Cement Industries-Barriers, Technologies and Policies. Paper prepared for OECD Green Growth and Sustainable Development Forum. 26-27 November. Paris: OECD.

Becker, G. (1993) Human Capital: A Theoretical and Empirical Analysis, with Special Reference to Education. 3rd edn. Chicago: University of Chicago Press. 
Campinos-Dubernet, M. and Grando, J.-M. (1991) 'Construction, constructions: a crossnational comparison', in The Production of the Built Environment, Proceedings of the 11 Bartlett International Summer School. Paris 1989, pp 17-34. London: University College London, Bartlett School.

Caren, V. and Astor, E.N. (2013) 'The potential for gender equality in architecture: an Anglo-Spanish comparison', Construction Management and Economics, 31(8), pp. 874-882.

Clancy, J. and Feenstra, M. (2019) Women, Gender Equality and the Energy Transition in the EU. Report requested by the Committee on Women's Rights and Gender Equality of the EU Parliament. European Union.

Clancy, J. and Feenstra, M. (2019) Women, Gender Equality and the Energy Transition in the EU. Policy Department for Citizens' Rights and Constitutional Affairs, European Parliament.

Clarke, L., Gleeson, C., Sahin-Dikmen, M. and Winch, C. (2019) Vocational Education and Training for Low Energy Construction (VET4LEC). i) Final Report for the European Commission and ii) Country Summaries, Brussels.

Clarke, L. and Sahin-Dikmen, M. (2018a) City Building (Glasgow): An Inspirational Model of Low Energy Social Housing and Public Building Production. York University, ON: ACW programme: https://adaptingcanadianwork.ca.

Clarke, L., Gleeson, C. and Winch, C. (2017a) 'What kind of expertise is needed for low energy construction?', Construction Management and Economics, 35(3), pp. 78-89.

Clarke, L., Gleeson, C. and Wall, C. (2017b), 'Women and low energy construction in Europe: a new opportunity?' in Cohen, M.G. (ed.) Climate Change and Gender in Rich Countries, pp 55-69. New York: Earthscan/Routledge.

Clarke, L., Michielsens E., Snijders, S., and Wall, C. (2015) No More Softly, Softly: Review of Women in the Construction Workforce. ProBE: University of Westminster https://core .ac.uk/download/pdf/161107132.pdf.

Clarke, L., Frydendal Pedersen, E., Michielsens, E., Susman, B. and Wall, C. (2004) Women in Construction. Brussels: CLR/Reed.

Clarke L., Michielsens E. and Snijders S. (2018b) 'Misplaced Gender diversity policies and practices in the British construction industry: developing and inclusive and transforming strategy', in Valuing People in Construction edited by Fidelis Emuze and John Smallwood, Taylor and Francis/Routledge.

Dainty, A., Neale, R.H. and Bagilhole, B. (1999) 'Women's careers in large construction companies: expectations unfulfilled?', Career Development International, 4(7), pp. 353-357.

ECSO (2020) Improving the Human Capital Basis. Analytical Reporter March. Brussels: European Construction Sector Observatory.

EDF (2013) Hinkley Point C Construction Project: Industrial Relations Common Framework Agreement. Electricité de France r.

EFBWW and FIEC (2020) Joint Reaction of European Social Partners of the Construction Industry on the Consultation on the Update of the Skills Agenda for Europe. January 29. Brussels: European Federation of Building and Woodworkers and the European Construction Industry Federation.

EPBD (2018) Directive 2018/844/EU of the European Parliament and of the Council of 30 May 2018 Amending Directive 2010/31/EU on the Energy Performance of Buildings and Directive 2012/27/EU on Energy Efficiency. Brussels: European Commission.

EPBD (2010) Directive 2010/31/EU of the European Parliament and of the Council of 18 May 2010 on the Energy Performance of Buildings. Brussels: European Commission. 
European Commission (EC) (2019a) Clean Energy for All Europeans. Directorate General for Energy. Brussels: European Commission.

European Commission (EC) (2019b) The European Green Deal. Brussels: European Commission.

European Commission (EC) (2018) Final Report on the Assessment of the Build UP Skills Pillar II. EASME. Brussels: European Commission.

European Commission (EC) (2016a) Synthesis Report on the National Plans for Nearly Zero Energy Buildings. JRC Science for Policy Report 97408. Brussels: European Commission.

European Commission (EC) (2016b) Evaluation of the Build Up Skills Initiative under the Intelligent Energy Europa Programme 2011-2015. EASME. Brussels: European Commission.

European Commission (EC) (2015) A Framework Strategy for a Resilient Energy Union with a Forward-Looking Climate Change Policy. Brussels: European Commission.

European Commission (EC) (2014) Build-up Skills: EU Overview Report, Staff Working Document. Intelligent Energy Europe. Brussels: European Commission.

European Commission (EC) (2010) Energy 2020_A Strategy for Competitive, Sustainable and Secure Energy. Brussels: European Commission.

European Construction Sector Observatory (ESCO) (2020) Improving the Human Capital Basis. Updated March. Brussels: European Commission.

European Institute for Gender Equality (EIGE) (2016a) Gender and Energy. Luxembourg: European Union.

European Institute for Gender Equality (EIGE) (2016b) Gender in Environment and Climate Change. Luxembourg: European Union.

European Institute for Gender Equality (EIGE) (2012) Review of the Implementation in the EU of Area K of the Beijing Platform for Action: Women and the Environment-Gender Equality and Climate Change. Luxembourg: European Union

European Parliament (2012a) Resolution of 20 April 2012 on Women and Climate Change (2011/2197(INI)). Luxembourg: European Parliament.

European Parliament (2012b) (Report on the Role of Women in the Green Economy,(2012/2035(INI)). Luxembourg: European Parliament.

European Commission (EC) (2020) A Union of Equality - Gender Equality Strategy 2020-2025. Brussels: European Commission.

European Parliament (2017) European Pillar of Social Rights.

European Parliament (2012c) Charter of Fundamental Rights of the European Union.

Eurostat (2016) Share of Men and Women in 20 Most Common Occupations. European Labour Force Survey.

Ferguson, S. (2020) Women and Work: Feminism, Labour and Social Reproduction. London: Pluto Press.

Fielden, S.L., Davidson, M.J., Gale, A.W., and Davey, C.L. (2000) 'Women in construction: the untapped resource', Construction Management and Economics, 18(1), pp.113-121.

Foster, J.B. (2002) Ecology Against Capitalism. New York: NYU Press.

Fraser, N. (2013) The Fortunes of Feminism: From State-Managed Capitalism to Neoliberal Crisis. London/New York: Verso.

Gleeson, C. (2016) 'Residential heat pump installations: the role of vocational education and training', Building Research and Information, 44(4), pp. 394-406.

Hampton, P. (2015) Workers and Trade Unions for Climate Solidarity - Tackling Climate Change in a Neoliberal World. London/ New York: Routledge.

ILO (2018) Greening with Jobs: World Employment Social Outlook. Geneva: International Labour Office. 
IRENA (2019) Renewable Energy: A Gender Perspective. Abu-Dhabi: International Renewable Energy Agency.

Johnston, D. (2016) 'Bridging the domestic building fabric thermal performance gap', Building Research and Information, 44(2), pp. 147-159.

Lundström, R. (2018) 'Greening transport in Sweden: the role of the organic intellectual in changing union climate change policy', Globalisations, 15(4), pp. 536-549.

MacGregor, S. (2017) Routledge Handbook of Gender and Environment. Abingdon and New York: Earthscan.

MacGregor, S. (2010) 'A stranger silence still: the need for feminist social research on climate change', Sociological Review, 57, pp. 124-140.

Machin, A. (2019) 'Changing the story? The discourse of ecological modernisation in the European Union', Environmental Politics, 28(2), pp. 208-227.

Maurice, M., Sellier, F. and Silvestre, J.J. (1986) The Social Foundations of Industrial Power-A Comparison of France and Germany. Cambridge, MA: MIT Press.

Mellor, M. (2017) 'Ecofeminist political economy: a green and feminist agenda', in MacGregor, S. (ed) Routledge Handbook of Gender and Environment. Abingdon and New York: Earthscan, pp. 86-100.

Mol, A.P.J., Sonnenfeld, D.A. and Spaargaren, G. (eds.) (2009) The Ecological Modernisation Reader: Environmental Reform in Theory and Practice. London/ New York: Routledge.

Parsons, H.L. (1977) Marx and Engels on Ecology. CT/London: Greenwood Publishing Group.

Pearl-Martinez, R. and Stephens J.C. (2016) 'Toward a gender diverse workforce in the renewable energy transition', Sustainability, Practice and Policy, 12(1), pp. 8-15.

Powell, A., Bagilhole, B. and Dainty, A. (2009) 'How women engineers do and 'undo' gender: consequences for gender equality', Gender Work and Organizations, 16(4), pp. 411-428.

Rottenberg, C. (2018) The Rise of Neoliberal Feminism. Oxford: Oxford University Press.

Sang, K. and Powell, A. (2013) 'Equality, diversity, inclusion and work-life balance in construction', in Dainty and Loosemore (eds) Human Resource Management in Construction Projects: Critical Perspectives. pp. 163-196. London: Routledge.

Styhre, A. (2011) 'The overworked site manager: gendered ideologies in the construction industry', Construction Management and Economics, 29(9), pp. 943-955.

Watts, J. (2009) 'Allowed into a man's world' meaning of work-life balance': perspectives of women civil engineers as 'minority workers' in construction', Gender Work and Organizations, 16(1), pp. 37-57.

Weiner, E. and MacRae, R. (2014) 'The persistent invisibility of gender in EU policy: Introduction', European Integration-Online Papers Special Issue, 18(1), Article 3.

Worrall, L., Harris, K., Stewart, R., Thomas, A. and McDermott, P. (2010) 'Barriers to women in the United Kingdom construction industry', Engineering, Construction and Architectural Management, 1(3), pp. 268-281.

Wright, T. (2014) The Women into Construction Project: An Assessment of a Model for Increasing Women's Participation in Construction. Centre for Research in Equality and Diversity, School of Business and Management, Queen Mary: University of London.

Zero Carbon Hub (2013) Closing the Gap Between Design and As-Built PerformanceInterim Progress Report. London: Zero Carbon Hub. 